Acta vet. scand. 1971, 12, 496-503.

From the Department of Physiology, Veterinary College of Norway, and the Institute of Animal Nutrition, Agricultural College of Norway, Vollebekk.

\title{
SERUM NON-ESTERIFIED \\ FATTY ACIDS AND PLASMA GLYCEROL AS INDICATORS OF FAT MOBILIZATION IN PREGNANT SHEEP SUBJECTED TO COLD STRESS
}

\author{
By \\ Arnfinn Aulie, Harald N. Astrup, Jon J. Nedkvitne \\ and Weiert Velle
}

The breeding season for sheep in Norway is in late fall, with the lambings occurring in April/May. During the winter the animals are mostly kept in barns and shorn shortly before the mating season and again in spring a few weeks before parturition. The removal of the fleece increases the thermal conductance considerably and the lower critical temperature increases from below zero to about $28^{\circ} \mathrm{C}$ (Blaxter 1962). In a cold environment this means that the animals must produce more heat to maintain the normal body temperature. This factor in itself increases the maintenance requirements of the ewes. In addition the pregnant state increases the requirements with about $40 \%$ (Modyanov 1969).

It would be of interest, then, to study the degree to which the ewes mobilize their body fat in order to meet the increased energy requirements, during gestation under controlled feeding conditions.

Plasma levels of non-esterified fatty acids (NEFA) and free glycerol (PG) are useful parameters of fat mobilization. NEFA may, however, be used directly by peripheral tissues as a source of energy, while the glycerol formed during the intracellular 
hydrolysis of triglycerides has to be phosphorylated in the liver before it can be metabolized further. Theoretically PG should, therefore, be a better indicator of fat mobilization than NEFA. While NEFA has been used in controlling the nutritional state of sheep (Russel et al. 1967), PG determinations do not seem to have been applied previously as indicators of fat mobilization in this species.

This paper reports changes in NEFA as well as PG during the gestational period in 15 ewes kept on controlled feed intake in an open barn.

\section{MATERIAL AND METHODS}

Fifteen healthy ewes of the Dala breed, varying between 73 and $91 \mathrm{~kg}$, were bred in late October. During the whole gestation period the ewes were given a daily ration of $0.054 \mathrm{~kg}(0.045 \mathrm{~kg}$ dry matter) high-quality hay per $\mathrm{kg}$ metabolic body weight ( $\mathrm{W}^{0.75}$ ), based on 2 weighings in late November. In addition to the hay, each animal received a daily supplement of $0.1 \mathrm{~kg}$ grain mixture with $15 \%$ minerals. The animals were kept in an open barn where the temperature changed with the outdoor temperature.

The mean and lowest temperatures in the barn were recorded on the days when blood sampling was made.

The ewes were shorn just before mating and again in $\mathrm{Fe}$ bruary about 5 weeks before parturition.

Blood samples were taken in the morning before feeding. For glycerol determinations, heparinized blood was immediately separated by centrifugation, and the plasma samples kept in polyethylen tubes at $-20^{\circ} \mathrm{C}$ until they could be analyzed. For non-esterified fatty acid determination serum was used.

Plasma free glycerol was measured enzymatically by use of the reagents produced by Boehringer (Germany). The method is based on the following reactions:

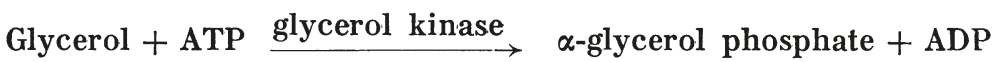
ADP + Phosphoenolpyruvate $\stackrel{\text { pyruvate kinase }}{\rightarrow}$ Pyruvate + ATP Pyruvate $+\mathrm{NADH}+\mathrm{H}^{+} \stackrel{\text { lactic dehydrogenase }}{\longrightarrow}$ Lactate $+\mathrm{NAD}^{+}$

The reaction was followed spectrophotometrically by recording the decrease in NADH at $334 \mathrm{~nm}$ (Pinter et al. 1967). 


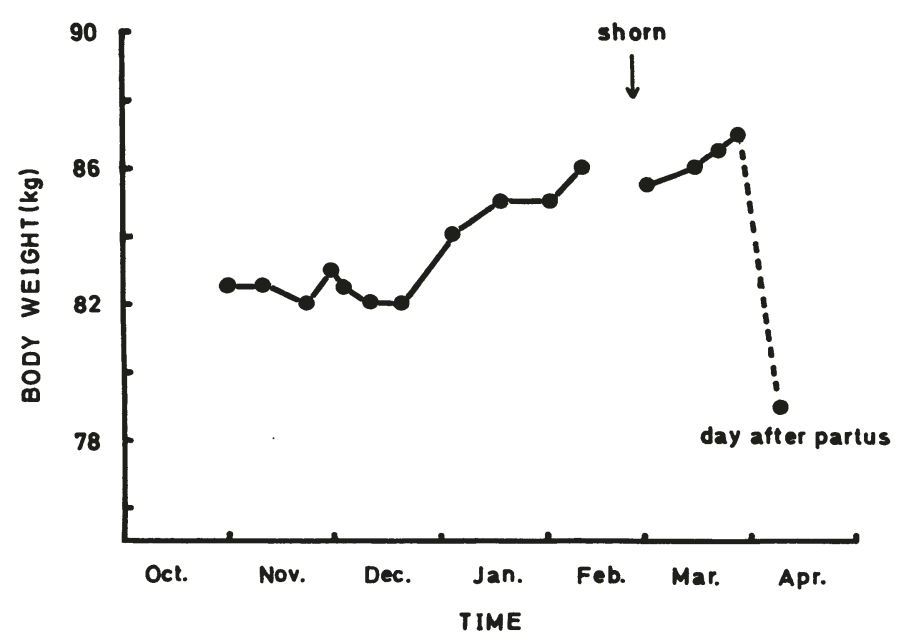

F i g u r e 1. The body weight of 15 Dala sheep during the gestation period. The last point indicates the mean body weight the day after parturition.

The assay as described in the Boehringer brochure is intended for human plasma. When sheep plasma was used, a substantial dehydrogenation of NADH was observed even before the addition of glycerol kinase. Correction for this "unspecific" decrease in absorbancy therefore had to be done for each analysis. The resulting corrected change in absorbancy multiplied by a factor of 10.8 gave the glycerol content in $\mathrm{mg}$ per $100 \mathrm{ml}$ of plasma.

Non-esterified fatty acids were determined according to the method described by Patterson (1963).

\section{RESULTS}

The body weights of the ewes were constant during the first 2 months of gestation, and thereafter slowly increased up to parturition (Fig. 1). The mean body weight the day after lambing was $3.5 \mathrm{~kg}$ less than the mean weight before mating, indicating undernourishment during part of the gestation period.

NEFA showed constant low values (mean $430 \mu \mathrm{eq} . / 1$ serum, $\mathrm{s} \pm 175, \mathrm{n}=15$ ) during the first 2 months of pregnancy, but increased considerably later (Fig. 2). The highest NEFA values (mean $2028 \mu \mathrm{eq} . / \mathrm{l}, \mathrm{s} \pm 438, \mathrm{n}=15$ ) were recorded in the first blood sample taken after shearing, with a subsequent drop and 


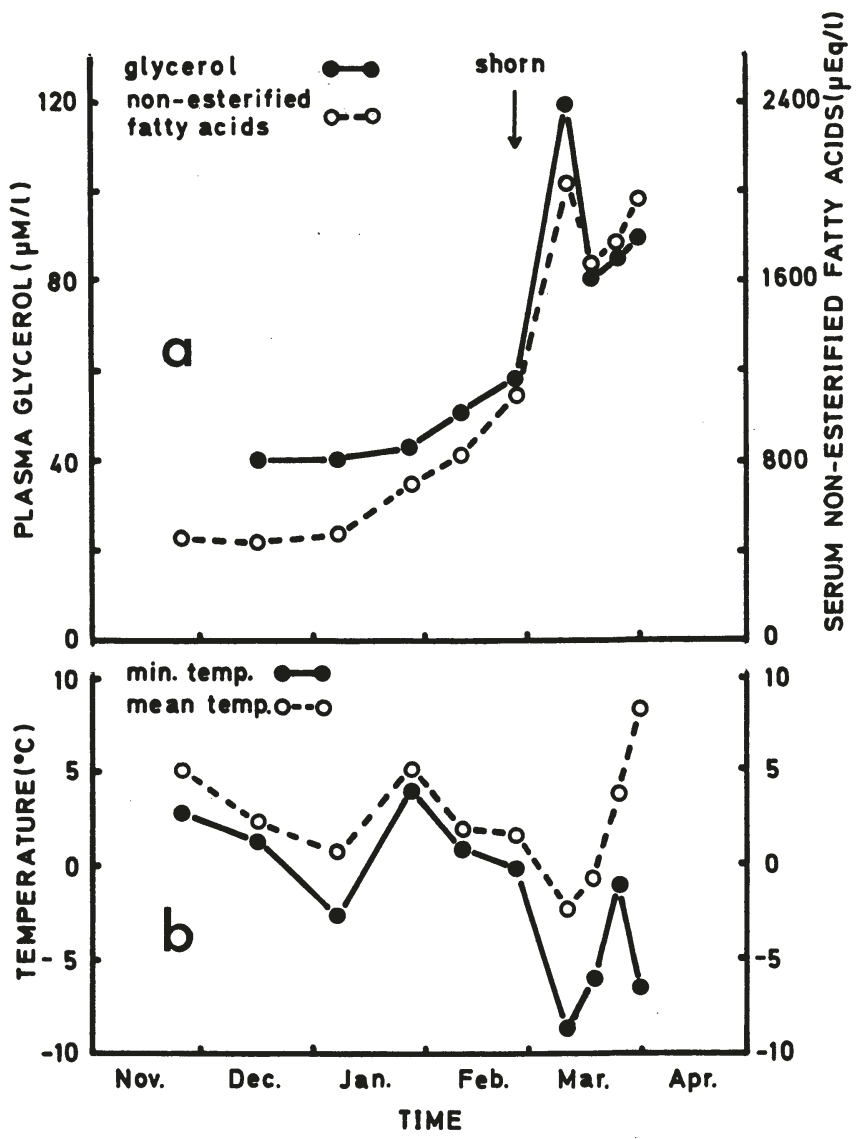

Figure 2. A: The plasma concentration of glycerol and free fatty acids during the gestation period.

B: The mean and lowest temperature in the barn on the day of sampling.

again a rise towards parturition when the values reached an average of $1893 \mu$ eq./l $(s \pm 544, n=10)$. PG followed the same pattern as NEFA during gestation, being low and constant during the first 2 months, $39 \mu \mathrm{mol} / \mathrm{l}$ plasma $(\mathrm{s} \pm 19, \mathrm{n}=15)$. The highest $\mathrm{PG}$ values $(119 \mu \mathrm{mol} / \mathrm{l}, \mathrm{s} \pm 28, \mathrm{n}=15)$ coincided with the peak NEFA values shortly after shearing. Just prior to parturition the average value was $89 \mu \mathrm{mol} / \mathrm{l}(\mathrm{s} \pm 41, \mathrm{n}=10$ ) (Fig. 2).

The mean temperatures in the barn on the days of blood sampling varied between 8.3 and $-2.4^{\circ} \mathrm{C}$, while the lowest tem- 
peratures on nights before sampling varied between 4.0 and $-8.8^{\circ} \mathrm{C}$. The lowest temperature in the barn coincided with the first blood sampling after shearing (Fig. $2 \mathrm{~B}$ ).

\section{DISCUSSION}

The constancy of the body weights and the low serum and plasma values for NEFA and PG during the first 2 months of pregnancy, indicate adequate feeding of the animals during this part of the gestation period. In the following months, when the energy requirement increased due to the advancing stage of pregnancy, the NEFA level increased and passed $750 \mu \mathrm{eq} . / 1$ in the beginning of February. This level has been reported by Russel et al. (1967) as indicating undernourishment in Scottish Blackface sheep.

In the present investigation one might have expected the NEFA concentration to level off at 1000-1200 $\mu$ eq./ 1 which by Russel et al. was found to correspond to a severe degree of undernourishment. However, the shearing, combined with the subsequent marked drop in the environmental temperature obviously induced a very strong increase in the metabolic rate not compensated by increased food intake. The resulting increase in fat mobilization is reflected in the further rise in the NEFA values

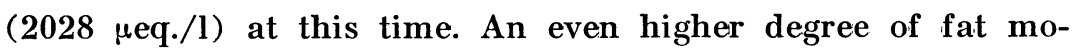
bilization has been reported by Halliday et al. (1969) on shorn sheep exposed to acute cold. The serum of these animals, who had previously been kept in a thermoneutral environment, reached a NEFA value of about $3500 \mu \mathrm{eq} . / 1$ after 1 day's exposure to $-20^{\circ} \mathrm{C}$.

The concomitant rise in the $\mathbf{P G}$ after shearing in this study further supports the assumption of a cold induced fat mobilization. The highest mean PG values $(119 \mu \mathrm{mol} / \mathrm{l})$ are actually of the same order of magnitude as those reported by Bergman (1968) for pregnant ketotic sheep fasted for 3-5 days a few weeks before parturition.

The closely similar patterns of NEFA and PG indicate that both substances are good parameters for the degree of fat mobilization.

Although the state of pregnancy by itself substantially increases the energy requirements of ewes, it is unlikely that this alone should induce an increase in fat mobilization of the mag- 


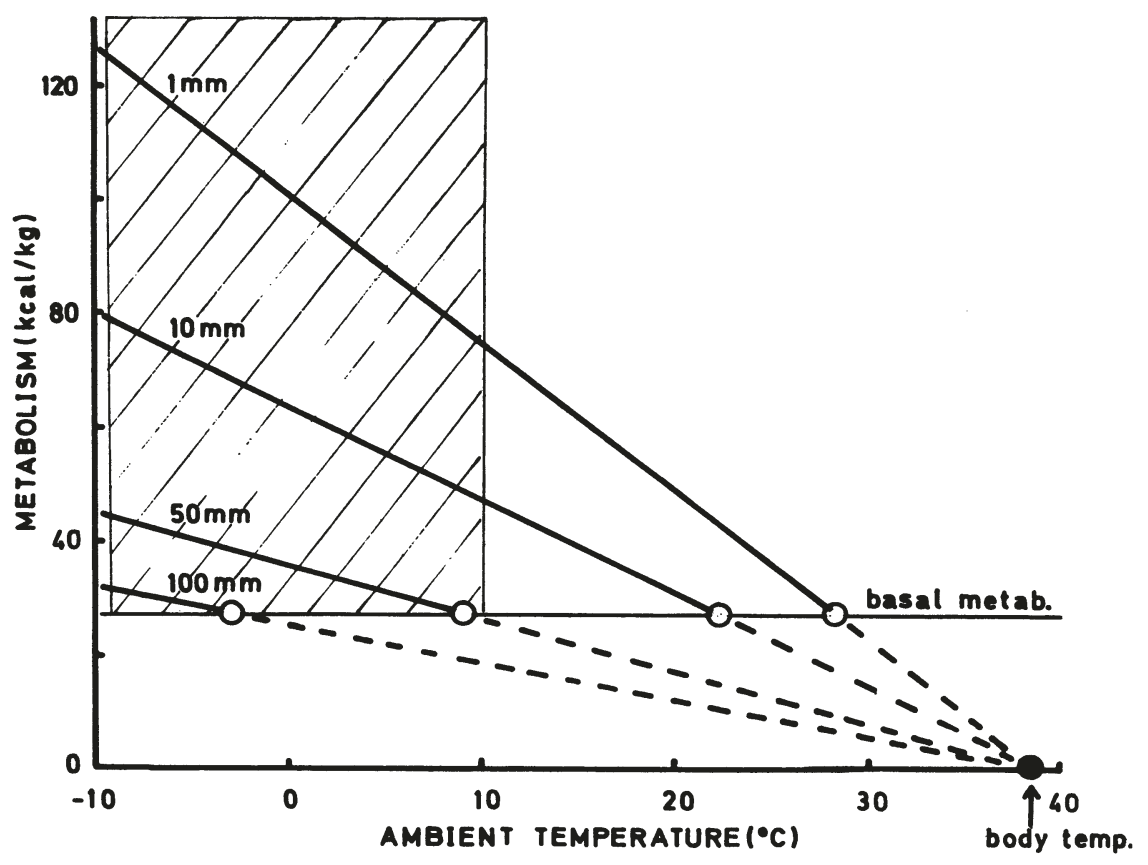

Figure 3. The relation between metabolism and ambient temperature at different fleece lengths. The figures on each line indicate the fleece thickness, and the shadowed area shows the temperature range in the barn the last third of the gestation period in the present experiment.

nitude indicated by the values recorded for NEFA and PG. In addition the shearing combined with the low temperature in the barn must have played an important role. A sheep with a fleece thickness of $100 \mathrm{~mm}$ has a lower critical temperature of $-3^{\circ}$, while a newly shorn sheep with a fleece of $1 \mathrm{~mm}$ thickness has a lower critical temperature of $28^{\circ}$ (Blaxter 1962). The ewes of the present investigation had a fleece length of $5-10 \mathrm{~mm}$ after shearing, corresponding to a critical temperature of about 26 $22^{\circ}$. According to Modyanov (1969) sheep of Caucasian breed have a resting metabolic rate of $26.8 \mathrm{kcal} . / \mathrm{kg}$ per day during the last third of pregnancy. Assuming the same critical temperatures as reported by Blaxter, one may construct a metabolic rate/ambient temperature diagram by drawing a line between the lower critical temperature and the body temperature in a coordinate system with the ambient temperature along the absissa and the 
metabolic rate along the ordinate (Scholander et al. 1950) as shown in Fig. 3. This diagram shows how the metabolic rate varies with the ambient temperature at different fleece thicknesses. The shadowed area indicates the temperature range in the barn during the last third of the gestation period in the present investigation. It is obvious that the animals were kept at an ambient temperature far below their critical temperature during this period. The ewes probably had to increase their metabolic rate after shearing 2-4 times the resting rate, in order to maintain their body temperature constant. This strong increase in the metabolic rate was not compensated by increased food intake, but resulted in a high degree of fat mobilization reflected by the marked rise in NEFA and PG during the last part of the gestation period.

\section{REFERENCES}

Bergman, E. N.: Glycerol turnover in the nonpregnant and ketotic pregnant sheep. Amer. J. Physiol. 1968, 215, 865-873.

Blaxter, K. L.: The Energy Metabolism of Ruminants. Hutchinson and Co. Ltd., London 1962.

Halliday, R., A. R. Sykes, J. Slee, A. C. Field \& A. J. F. Russel: Cold exposure of Southdown and Welsh mountain sheep. Animal Prod. 1969, 11, 479-491.

Modyanov, A. V.: Energy metabolism of sheep under different physiological conditions. In Energy Metabolism of Farm Animals. Ed. K. L. Blaxter, J. Kielanowski and Grete Thorbek. Oriel Press Limited 1969.

Patterson, D. S. P.: Some observations on the estimation of nonesterified fatty acid concentrations in cow and sheep plasma. Res. Vet. Sci. 1963, 4, 230-237.

Pinter, J. K., J. A. Hayashi \& J. A. Watson: Enzymic assay of glycerol, dihydroxyacetone and glyceraldehyde. Arch. Biochem. 1967, $121,404-414$.

Russel, A. J. F., J. M. Doney \& R. L. Reid: The use of biochemical parameters in controlling nutritional state in pregnant ewes, and the effect of undernourishment during pregnancy on lamb birth-weight. J. agric. Sci. (Camb.) 1967, 68, 351-358.

Scholander, P. F., R. Hock, V. Walters, F. Johnson \& L. Irvin: Heat regulation in some arctic and tropical mammals and birds. Biol. Bull. 1950, 99, 237--258. 


\section{SUMMARY}

Fifteen pregnant ewes in an open barn were kept on a constant hay diet during the whole gestation period. The ewes were shorn as usually in fall and spring. The serum non-esterified fatty acids (NEFA) and the plasma glycerol (PG) content were followed during the gestation.

The body weight, NEFA and PG values were rather constant during the first 2 months of gestation (NEFA: $430 \pm 175 \mu$ eq./1 serum, PG: $39 \pm 19 \mu \mathrm{mol} / 1$ plasma) indicating an adequate feeding during this period. NEFA and PG showed thereafter a parallel increase and reached maximal values at the first sampling after shearing which coincided with a marked drop in environmental temperature. NEFA was then $450 \%$ and PG about $340 \%$ of the normal values, indicating a strong increase in fat mobilization in this period. The shearing reduces the isolation property of the fur considerably, and the ewes have to produce extra heat to maintain the normal body temperature at low environmental temperatures. The metabolic rate after shearing was estimated to have been $2-4$ times the basal rate at the temperatures in the barn. This strong increase in the metabolic rate was not compensated by an increased food intake, but resulted in increased fat mobilization.

\section{SAMMENDRAG}

Serum uforestrede fettsyrer og plasma glyserol som indikatorer på fettmobilisering hos drektige sфyer utsatt for kuldepåkjenning.

Femten drektige sauer holdt i sauefjøs ble satt på en konstant høyforing under hele drektigheten. Sauene ble klippet som vanlig høst og vår. Konsentrasjonen av fri fettsyrer (NEFA) i serum og fritt glycerol (PG) i plasma ble bestemt gjentatte ganger i løpet av drektighetsperioden.

Kroppsvekten, NEFA og PG holdt seg ganske konstante de to første månedene av drektighetsperioden (NEFA: $430 \pm 175 \mu \mathrm{eq} . / 1$ serum, PG: $39 \pm 19 \mu \mathrm{mol} / 1$ plasma) noe som tyder på adekvat foring. NEFA og PG $\dot{P}$ kte deretter parallellt og nådde maksimalverdier ved f $\varnothing$ rste prøvetaking etter vårklipping. NEFA var da $450 \%$ og $\mathrm{PG} 340 \%$ av normalverdiene og indikerte en sterk $\varnothing \mathrm{kning}$ av fettomsetningen.

Klipping vil nedsette pelsens isolasjonsevne sterkt og sauene må produsere ekstra varme for ả holde en konstant kroppstemperatur ved lave temperaturer i omgivelsene. Energiomsetningen etter klipping ble beregnet til 2-4 ganger basalomsetningen ved de aktuelle fjøstemperaturer. Denne sterke $\phi$ kningen i energiomsetningen ble ikke kompensert ved $\varnothing$ ket forinntak, men resulterte i $\varnothing$ ket fettomsetning.

(Received September 14, 1970). 